\title{
Editorial
}

\section{Estranhas coincidências}

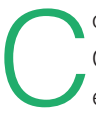

omo já ocorreu em edições passadas, a Revista Brasileira de Aplicações de Vácuo (RBAV) recebe uma seleção de artigos do Congress of Industrial Management and Aeronautical Technology (CIMATech). O que esse evento - com foco bem específico em atender à área de aeronáutica - tem em comum com as edições anteriores da revista? O estudo de conteúdo feito nos resumos dos artigos publicados na revista em 2018 e 2019, comparando tanto a submissão em fluxo contínuo quanto pelo CIMATech

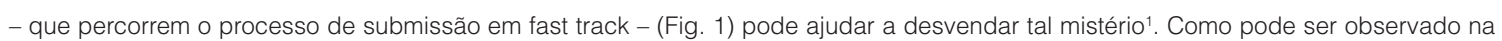
Fig. 1, que apresenta as 500 palavras mais utilizadas nos respectivos textos, há palavras comuns aos dois campos, como materiais (ou material) e filmes, ou mesmo termos muito próximos, como MEV e microscopia, além de similaridades bastante interessantes. Enquanto no CIMATech o termo polímero é comum, nos artigos em fluxo contínuo é mais recorrente PET e OLEDs. Alumínio aparece como substrato importante para um e silício para outro, o que provavelmente explica o uso de termos como componentes e dispositivos, respectivamente. Igualmente interessante é o uso dos termos aço e liga. E o que dizer do interesse pela interface nos textos do CIMATech, enquanto superfície é mais recorrente para os artigos submetidos em fluxo contínuo?

Assim, se seu resumo dependesse dos termos, e respectivas frequências, usados nos quatro últimos números da revista, seria possível explicar seu processo (14 ocorrências) ou processos (oito ocorrências) descrevendo, cuidadosamente, seu material (10 ocorrências) ou materiais (10 ocorrências) utilizados, observando que parâmetros (oito ocorrências) teriam análises (três ocorrências) de superfície (nove ocorrências), possivelmente por microscopia (seis ocorrências). No caso de soldagem (12 ocorrências), energia (nove ocorrências) ou potencial (oito ocorrências) do equipamento seria informado. O gás (nove ocorrências) ou gases (oito ocorrências) utilizados seriam perfeitamente descritos, juntamente com a informação da pressão (seis ocorrências) e de como a corrosão (nove ocorrências) foi evitada. Se seu substrato for uma liga (seis ocorrências) ou ligas (duas ocorrências), provavelmente será aço (seis ocorrências) na forma de arame (seis ocorrências).

O mundo moderno tornou-se complexo, intrincado, transdisciplinar. Nesse contexto, algumas tecnologias tornaram-se suporte para toda essa evolução, como é o caso da tecnologia de vácuo, e expandiram-se tão intrincadamente que, atualmente, sua presença é tão corriqueira que muitas vezes nem é percebida. Assim foi a percepção de alguns pioneiros que consideraram a tecnologia de vácuo o caminho para o desenvolvimento tecnológico; o resto é história.

Rotas, caminhos, interatividade, todos trazidos há 40 anos pela nossa Sociedade Brasileira de Vácuo. Que possamos manter assim pelos próximos 40 !
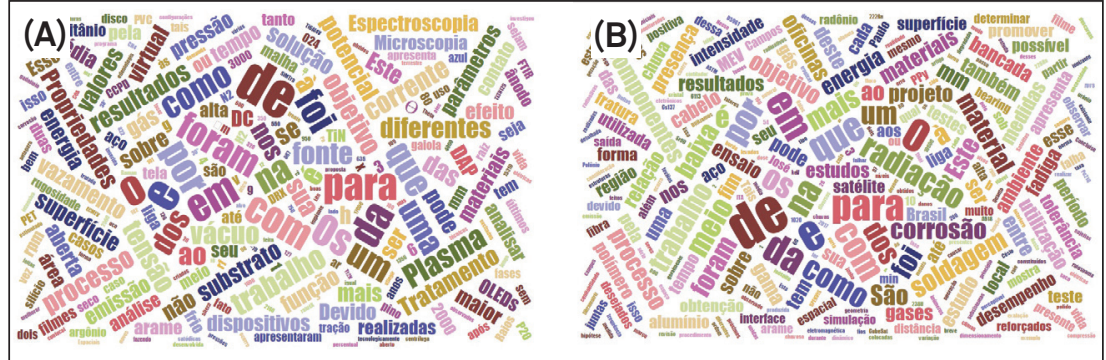

Figure 1: As 500 palavras mais utilizadas nos resumos da revista em 2018 e 2019, nos (A) artigos submetidos em fluxo contínuo ou (B) pelo CIMATech'1

\section{AGRADECIMENTOS}

A Leandro Colevati dos Santos e Eliphas Wagner Simões, pela discussão sobre análise de conteúdo.

Maria Lúcia Pereira da Silva

Editora-chefe

\section{REFERÊNCIAS}

1. Jason Davies [Internet]. Wordcloud; c2004-2017 [citado em 16 de abril de 2019]; Disponível em: https://www.jasondavies.com/wordcloud/ 


\title{
Editorial
}

\section{Strange coincidences}

$\Lambda$ s has already happened in previous editions, the Brazilian Journal of Vacuum Applications (Revista Brasileira de Aplicações de Vácuo - RBAV) receives a selection of articles from the Congress of Industrial Management and Aeronautical Technology (CIMATech). What does this event - with a specific focus on serving the aeronautics area - has in common with previous editions of the magazine? The study of the contents in the abstracts of the articles published in the magazine in 2018 and 2019, comparing both the submission in a stream and by CIMATech - that goes through the process of submission in fast track - (Fig. 1) may help to unveil such a mystery ${ }^{1}$. As can be observed in Fig. 1, which presents the 500 words most commonly used in the respective texts, there are words common to both fields, such as materials (or material) and films, or even very close terms such as MEV and microscopy, as well as quite interesting similarities. While in the CIMATech the term polymer is common, in the continuous flow articles PET and OLEDs are more recurring. Aluminum appears as an important substrate for one and silicon to another, which probably explains the use of terms like components and devices, respectively. Equally interesting is the use of the terms steel and alloy. And what about the interest in the interface in CIMATech texts, while the surface is more recurrent for articles submitted in a continuous stream?

Thus, if their abstract depending on the terms and frequencies used in the last four issues of the journal, it would be possible to explain their process (14 occurrences) or processes (eight occurrences) by carefully describing their material (10 occurrences) or materials (10 occurrences) used, observing that parameters (eight occurrences) would have analyzes (three occurrences) of surface (nine occurrences), possibly by microscopy (six occurrences). In the case of welding (12 occurrences), energy (nine occurrences) or potential (eight occurrences) of equipment would be informed. Gas (nine occurrences) or gases (eight occurrences) used would be perfectly described, along with pressure information (six occurrences) and how corrosion (nine occurrences) was avoided. If its substrate is an alloy (six occurrences) or alloys (two occurrences), it will probably be steel (six occurrences) in the form of wire (six occurrences).

The modern world has become complex, intricate, transdisciplinary. In this context, some technologies have become a support for all this evolution, as is the case with vacuum technology, and have expanded so intricately that their presence today is so commonplace that it is often not even noticed. Thus was the perception of some pioneers who considered the technology of vacuum the way for technological development; the rest is history.

Routes, paths, interactivity, all brought 40 years ago by ourSociedade Brasileira de Vácuo. May we keep this for the next 40 !
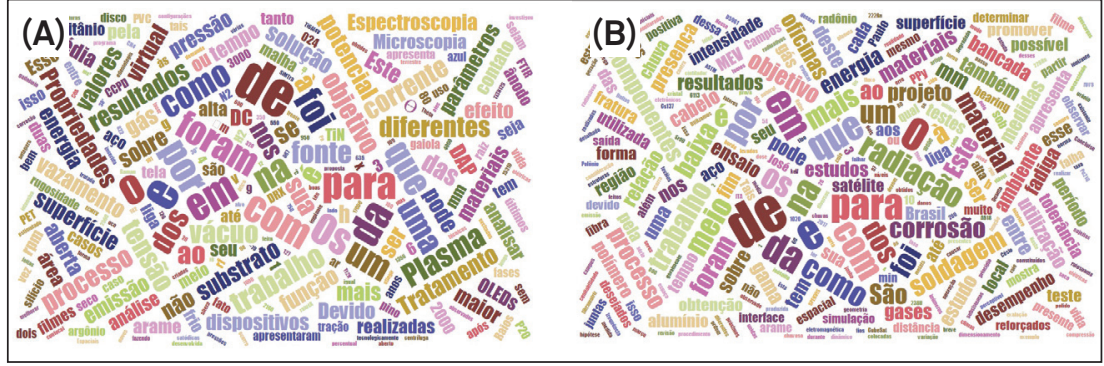

Figure 1: The 500 most used words in the journal's abstracts in Portuguese between the year 2018 and 2019, in (A) articles submitted in continuously or (B) by CIMATech'1. (This Figure analyzes the Portuguese language, similar results can be obtained using English abstract)

\section{ACKNOWLEDGMENT}

Leandro Colevati dos Santos and Eliphas Wagner Simões for the discussion on content analysis.

\author{
Maria Lúcia Pereira da Silva
}

Editor-in-chief

\section{REFERÊNCIAS}

1. Jason Davies [Internet]. Wordcloud; c2004-2017 [cited in 16 April 2019]; Available at: https://www.jasondavies.com/wordcloud/ 